\title{
Article/Artigo
}

\section{Class-I human leukocyte alleles in leprosy patients from Southern Brazil}

\author{
Alelos leucocitários humanos em pacientes com hanseníase do sul do Brasil
}

\author{
Danilo Santana Alessio Franceschi ${ }^{1}$, Luiza Tamie Tsuneto ${ }^{1}$, Priscila Saamara Mazini ${ }^{1}$, William Sergio do \\ Sacramento ${ }^{1}$, Pâmela Guimarães Reis ${ }^{1}$, Cristiane Conceição Chagas Rudnick ${ }^{1}$, Samaia Laface Clementino ${ }^{1}$, \\ Ana Maria Sell ${ }^{1}$ and Jeane Eliete Laguila Visentainer ${ }^{1}$
}

\begin{abstract}
Introduction: The present study was designed to investigate a possible role of HLA (histocompatibility leucocyte antigen) class-I alleles (HLA-A, -B, and -C) in leprosy patients from Southern Brazil. Methods: Two hundred and twenty-five patients with leprosy and 450 individuals for the control group were involved in this research. HLA genotyping was performed through PCR-SSO protocols (One Lambda, USA); the frequency of these alleles was calculated in each group by direct counting, and the frequencies were then compared. Results: There was an association between HLA-A*11 (6.9\% vs 4.1\%, $\mathrm{p}=0.0345$, OR $=1.72$, 95\% $\mathrm{CI}=1.05-2.81)$, HLA-B 38 (2.7\% vs. $1.1 \%, \mathrm{p}=0.0402$, $\mathrm{OR}=2.44,95 \% \mathrm{CI}=1.05-5.69)$, HLA-C ${ }^{*} 12$ (9.4\% vs. $\left.5.4 \%, \mathrm{p}=0.01, \mathrm{OR}=1.82,95 \% \mathrm{CI}=1.17-2.82\right)$, and HLA-C ${ }^{*} 16(3.1 \%$ vs. $6.5 \%, \mathrm{p}=0.0124, \mathrm{OR}=0.47,95 \% \mathrm{CI}=0.26-0.85)$ and leprosy per se. In addition, HLA-B 35 , HLA-C*04, and HLA-C*07 frequencies were different between lepromatous (LL) and tuberculoid (TT) patients. However, after adjusting for the number of alleles compared, Pc values became nonsignificant. Conclusions: Although our results do not support the previous findings that HLA class-I alleles play a role in leprosy pathogenesis, we suggest new studies because of the importance of the association between the HLA and KIR in the innate immune response to leprosy.
\end{abstract}

Keywords: HLA class-I genes. Leprosy. Mycobacterium leprae. Genetic susceptibility.

\section{RESUMO}

Introdução: $O$ presente estudo foi desenhado para investigar um possível papel para os alelos HLA (histocompatibility leucocyte antigen) de classe I ( $H L A-A,-B$, and -C) em pacientes com hanseníase do sul do Brasil. Métodos: Duzentos e vinte e cinco pacientes com hanseníase e 450 indivíduos para o grupo-controle foram envolvidos nesse estudo. O genótipo HLA foi determinado por protocolos PCR-SSO (One Lambda, USA) e, a frequência desses alelos foi calculada em cada grupo por contagem direta e, após, comparadas. Resultados: Houve associação entre $H L A-A^{*} 11(6,9 \%$ vs $4,1 \% ; \mathrm{p}=0,0345 ; \mathrm{OR}=1,72 ; \mathrm{CI}=1,05-2,81), H L A-B^{*} 38$ $(2,7 \%$ vs 1,$1 ; \mathrm{p}=0,0402 ; \mathrm{OR}=2,44 ; \mathrm{CI} 95 \%=1,05-5,69), H L A-C^{*} 12(9,4 \%$ vs $5,4 \% ; \mathrm{p}=0,01$; $\mathrm{OR}=1,82$; CI 95\% = 1,17-2,82) e HLA-C*16 (3,1 vs 6,5\%; $\mathrm{p}=0,0124 ; \mathrm{OR}=0,47$; CI 95\% = 0,26-0,85) e hanseníase per se. Além disso, as frequências de HLA-B*35, HLA-C $C^{*} 04 \mathrm{e} H L A-C^{*} 07$ foram diferentes entre os pacientes com as formas lepromatosa (LL) e tuberculoide $(\mathrm{TT})$. Contudo, após o ajuste para o número de alelos comparados, os valores de p se tornaram não significativos. Conclusões: Embora nossos resultados não sustentem as conclusões anteriores de que os alelos HLA de classe I desempenham um papel na associação com a patogênese da hanseníase, sugerimos novos estudos devido à importância da associação entre HLA e KIR na resposta imune inata à hanseníase.

Palavras-chaves: Genes HLA de classe I. Hanseníase. Mycobacterium leprae. Susceptibilidade genética.

1. Laboratório de Imunogenética, Departamento de Ciências Básicas da Saúde, Universidade Estadual de Maringá, PR.

Address to: Dra. Jeane Eliete Laguila Visentainer. Dept ${ }^{\circ}$ Ciências Básicas da Saúde/UEM. Av. Colombo 5790, 87020-900 Maringá, PR, Brasil.

Phone: 5544 3011-4864; Fax: 5544 3011-4931

e-mail: jelvisentainer@uem.br; jelvisentainer@gmail.com

Received in 18/04/2011

Accepted in 09/06/2011

\section{INTRODUCTION}

Leprosy is a chronic mycobacterial infection caused by the intracellular macrophage pathogen Mycobacterium leprae ${ }^{1}$, with about 260,000 new cases per year'. A major proportion of the leprosy cases remaining in the world are in India and a few other countries such as Brazil.

The more benign paucibacillary $(\mathrm{PB})$ forms, borderline tuberculoid (BT) and tuberculoid tuberculoid (TT), are characterized by the predominance of a Th1-type immune response. In contrast, in the multibacillary $(\mathrm{MB})$ forms, borderline borderline (BB), borderline lepromatous (BL) and lepromatous leprosy (LL), Th2-type immune response is responsible for the high antibody levels ${ }^{3}$.

The variability of the host response to infection seems to be genetically and environmentally influenced. The major histocompatibility complex (MHC), located on the short arm of human chromosome $6 \mathrm{p} 21$, is a candidate region for controlling disease susceptibility. The influence of the MHConantigen presentation to T cellsmaybe directly responsible for the genetic susceptibility to disease ${ }^{4}$.

In humans, histocompatibility leucocyte antigen (HLA) molecules are cell surface glycoproteins divided into two classical groups: HLA class-I (A, B, and $\mathrm{Cw}$ ) and class-II (DR, DQ and DP) antigens. The class-I loci encode molecules that bind antigenic epitopes usually derived from intracellular pathogens and present them to CD $8+\mathrm{T}$ cells, thereby initiating a cytotoxic $\mathrm{T}$ cell response. The class-II loci specify molecules that primarily bind peptides of extracellular origin and present them to CD4+T cells, resulting in cytokine production and $\mathrm{T}$ cell help in the antibody production.

The most consistent findings are for associations between HLA class-II alleles and leprosy. Many studies in India, Brazil, and China showed a positive association of HLA-DRB1* 15 and DRB1* 16 alleles and leprosy per se or subtypes ${ }^{5-12}$ and a negative 
association of HLA-DRB1*04 and leprosy per se or LL form ${ }^{9-10,12-13}$. Moreover, other studies have been summarized in several reviews ${ }^{14-17}$.

Some results have been found for class-I HLA alleles. HLA-B 46 allele was associated with multibacillary leprosy cases in South China ${ }^{18}$; while, in Turkey, HLA-A9, A10, A32, B5, B21, Bw4, Bw6, $\mathrm{Cw} 1$, and $\mathrm{Cw} 2$ were associated with leprosy susceptibility ${ }^{19}$. In India, while several HLA class-I antigens were associated with susceptibility to leprosy (HLA-A2, A11, B40, and Cw7), others were associated to protection $(\mathrm{A} 28, \mathrm{~B} 12 \text {, and } \mathrm{Cw} 4)^{20}$. HLA class-I alleles were also determined in multibacillary leprosy patients, resulting in a positive association with $H L A-A^{*} 02: 06, A^{*} 11: 02, B^{*} 18: 01, B^{*} 51: 10, C^{*} 04: 07$, and $C^{*}$ 07:03 alleles, and in a negative association with $C^{*} 04: 11^{21}$.

Therefore, this study aims at evaluating the influence of HLA class-I alleles on the susceptibility or resistance to leprosy and their clinical forms in Southern Brazilians.

\section{METHODS}

\section{Patients and controls}

Two hundred and twenty-five patients with leprosy assisted at $15^{\text {th }}$ Regional de Saúde do Estado do Paraná, Maringá, Brazil were involved in this study. All the patients were from Paraná, Brazil. The individuals were classified in four distinct groups according to clinical and laboratorial observations offered by the dermatologist responsible for leprosy diagnosis: TT (46; 20.4\%), LL (88; 39.1\%), B $(66 ; 29.3 \%)$, and indeterminate $(23 ; 10.2 \%)$; two patients had no defined observation. Patient's age varied between 22 and 82 years $(53.7 \pm 13.0)$; 97 were female, and 128 were male. Volunteers who were identified through a questionnaire as positive for other infectious or auto-immune diseases were excluded from the study.

The control group was constituted of 450 healthy subjects matched according to age, sex, ethnic group, and occupation, with no history of HLA-associated diseases and other demographic parameters. They were typified by Laboratório de Imunogenética at Universidade Estadual de Maringá. Control's age varied between 13 and 89 years $(37.1 \pm 12.3)$; 240 were female, and 210 were male.

Paranás population is predominantly of European origin (80.6\%), with a small but significant contribution of African (12.5\%) and Amerindian (7\%) genes ${ }^{22}$. In this study, both patients $(60.4 \%$ of European and $39.6 \%$ African origin) and controls (63.6\% of European and $36.4 \%$ African origin) were classified as mixed ethnic groups, according to phenotypic characteristics, as according to Parra et al..$^{23}$, in Brazil, at an individual level, skin color determined by physical evaluation is a poor predictor of genomic African ancestry.

The risk of population stratification bias due to differences in the ethnic background between patients and controls and variations of allele frequencies according to ethnic background was minimized by including patients and controls matched for the same ethnic background, residing in the same geographical area of leprosy prevalence.

\section{DNA extraction}

Venous blood samples $(10 \mathrm{~mL})$ were collected from the subjects, centrifuged for obtaining the buffy-coat and conserved at $-20^{\circ} \mathrm{C}$ until the use. The genomic DNA was extracted by EZ-DNA (Biological Industries ${ }^{\circledR}$, Kibbutz Beit Haemek, Israel) or Neoscience (One Lambda ${ }^{\circledR}$, CA, USA) kits from $150 \mu \mathrm{L}$ of frozen blood, and then stored in a freezer at $-20^{\circ} \mathrm{C}$.

\section{Determination of alleles of the HLA system}

After the evaluation of DNA purity and adjusting the concentration by optical density, HLA class-I alleles were genotyped by polymerase chain reaction-sequence specific of oligonucleotides (PCR-SSO) protocols with the Luminex 100xMAP flow cytometry dual-laser system to quantify fluorescently labelled oligonucleotides attached to color-coded microbeads (One Lambda ${ }^{\circledR}, \mathrm{CA}, \mathrm{USA}$ ), according to the manufacturer's instructions.

\section{Statistical analysis}

The frequency of alleles was obtained through direct counting of the alleles and expressed as percentage frequency. The data were tested for their fit to Hardy-Weinberg equilibrium by calculating the expected frequencies of the genotypes and comparing them with the observed values using the Arlequin software, version 3.1, available at http://cmpg.unibe.ch/software/arlequin3.

The analysis of the association between the HLA variables and the occurrence of leprosy types was performed using Fisher's exact test, with the Graph Pad Software program (San Diego, CA, USA), available at http://www.graphpad.com/quickcalcs/contingency1.cfm.

The odds ratio (OR) with 95\% confidence intervals (95\% CI) was calculated using SISA statistics online, available at http://www. quantitativeskills.com/sisa/index.htm, to evaluate the risk of the individual to develop the disease having an HLA type. Data were considered statistically significant when $\mathrm{p}<0.05$.

As each individual is tested for several HLA alleles and the same data were used for comparing the frequencies, it is possible that one of the alleles will by chance deviate significantly. To overcome this error, the $\mathrm{p}$ value is corrected by the use of Bonferroni inequality method, that is, by multiplying it with the number of alleles compared in each locus.

\section{Ethical considerations}

All the participants signed written informed consent forms, authorizing the use of their samples in this study, which was approved by the Ethics Committee for Human Research of the Universidade Estadual de Maringá.

\section{RESULTS}

Table 1 summarizes the allele frequencies of class-I HLA alleles in leprosy per se and control populations and the results of the association analyses. Conformation to Hardy-Weinberg proportions was examined at all loci in the control group, and the examination did not show any deviation ( $\mathrm{p}>0.05)$.

There was a positive association between leprosy per se and $H L A-A^{*} 11$ (6.9\% vs $\left.4.1 \%, \mathrm{p}=0.0345, \mathrm{OR}=1.72,95 \% \mathrm{CI}=1.05-2.81\right)$, $H L A-B^{*} 38$ (2.7\% vs $\left.1.1 \%, \mathrm{p}=0.0402, \mathrm{OR}=2.44,95 \% \mathrm{CI}=1.05-5.69\right)$, and $H L A-C^{*} 12(9.4 \%$ vs $5.4 \%, \mathrm{p}=0.01, \mathrm{OR}=1.82,95 \% \mathrm{CI}=1.17-$ 2.82 ), and negative association with $H L A-C^{*} 16$ (3.1\% vs $6.5 \%$, $\mathrm{p}=0.0124, \mathrm{OR}=0.47,95 \% \mathrm{CI}=0.26-0.85$ ).

Percent allele frequencies of class-I HLA alleles in opposite poles of leprosy are represented in Table 2 . The frequencies of $H L A-B^{*} 35$ and $H L A-C^{*} 04$ were lower in LL as compared with $T T$ patients, while the frequency of $H L A-C^{*} 07$ was higher. Therefore, our association analysis of stratified patient groups indicates that $H L A-B^{*} 35$ and $H L A-C^{*} 04$ could be protective alleles against LL leprosy, while $H L A-C^{*} 07$ could predispose to this form of disease. 
TABLE 1 - Human leukocyte antigens class-I allelic frequencies in patients with leprosy per se compared with those in control subjects.

\begin{tabular}{|c|c|c|c|c|c|c|c|c|c|c|c|c|c|c|}
\hline \multirow[b]{2}{*}{ HLA } & \multicolumn{2}{|c|}{$\begin{array}{l}\text { Leprosy } \\
(\mathrm{N}=224)\end{array}$} & \multicolumn{2}{|c|}{$\begin{array}{l}\text { Controls } \\
(\mathrm{N}=446)\end{array}$} & \multirow[b]{2}{*}{ HLA } & \multicolumn{2}{|c|}{$\begin{array}{l}\text { Leprosy } \\
(\mathrm{N}=223)\end{array}$} & \multicolumn{2}{|c|}{$\begin{array}{l}\text { Controls } \\
(\mathrm{N}=446)\end{array}$} & \multirow[b]{2}{*}{ HLA } & \multicolumn{2}{|c|}{$\begin{array}{l}\text { Leprosy } \\
(\mathrm{N}=224)\end{array}$} & \multicolumn{2}{|c|}{$\begin{array}{l}\text { Controls } \\
(\mathrm{N}=418)\end{array}$} \\
\hline & $\mathrm{n}$ & $\%$ & $\mathrm{n}$ & $\%$ & & $\mathrm{n}$ & $\%$ & $\mathrm{n}$ & $\%$ & & $\mathrm{n}$ & $\%$ & $\mathrm{n}$ & $\%$ \\
\hline$A^{*} 01$ & 41 & 9.2 & 79 & 8.9 & $B^{*} 07$ & 43 & 9.6 & 60 & 6.7 & $C^{*} 01$ & 16 & 3.6 & 22 & 2.6 \\
\hline$A^{*} 02$ & 119 & 26.6 & 228 & 25.6 & $B^{*} 08$ & 15 & 3.4 & 52 & 5.8 & $C^{*} 02$ & 18 & 4.0 & 52 & 6.2 \\
\hline$A^{*} 03$ & 48 & 10.7 & 85 & 9.5 & $B^{*} 13$ & 12 & 2.7 & 16 & 1.8 & $C^{*} 03$ & 37 & 8.3 & 82 & 9.8 \\
\hline$A^{*} 11^{a}$ & 31 & 6.9 & 37 & 4.1 & $B^{*} 14$ & 21 & 4.7 & 46 & 5.2 & $C^{*} 04$ & 79 & 17.6 & 120 & 14.4 \\
\hline$A^{*} 23$ & 21 & 4.7 & 48 & 5.4 & $B^{*} 15$ & 36 & 8.1 & 78 & 8.7 & $C^{*} 05$ & 26 & 5.8 & 64 & 7.7 \\
\hline$A^{*} 24$ & 37 & 8.3 & 83 & 9.3 & $B^{*} 18$ & 26 & 5.8 & 64 & 7.2 & $C^{*} 06$ & 35 & 7.8 & 69 & 8.3 \\
\hline$A^{*} 25$ & 6 & 1.3 & 13 & 1.5 & $B^{*} 27$ & 3 & 0.7 & 16 & 1.8 & $C^{*} 07$ & 113 & 25.2 & 209 & 25.0 \\
\hline$A^{*} 26$ & 17 & 3.8 & 31 & 3.5 & $B^{*} 35$ & 60 & 13.5 & 90 & 10.1 & $C^{*} 08$ & 18 & 4.0 & 40 & 4.8 \\
\hline$A^{*} 29$ & 19 & 4.2 & 44 & 4.9 & $B^{*} 37$ & 6 & 1.3 & 13 & 1.5 & $C^{*} 12^{c}$ & 42 & 9.4 & 45 & 5.4 \\
\hline$A^{*} 30$ & 18 & 4.0 & 60 & 6.7 & $B^{*} 38^{b}$ & 12 & 2.7 & 10 & 1.1 & $C^{*} 14$ & 17 & 3.8 & 15 & 1.8 \\
\hline$A^{*} 31$ & 29 & 6.5 & 45 & 5.0 & $B^{*} 39$ & 20 & 4.5 & 33 & 3.7 & $C^{*} 15$ & 17 & 3.8 & 42 & 5.0 \\
\hline$A^{*} 32$ & 9 & 2.0 & 21 & 2.4 & $B^{*} 40$ & 19 & 4.3 & 44 & 4.9 & $C^{*} 16^{d}$ & 14 & 3.1 & 54 & 6.5 \\
\hline$A^{*} 33$ & 12 & 2.7 & 23 & 2.6 & $B^{*} 41$ & 4 & 0.9 & 12 & 1.3 & $C^{*} 17$ & 14 & 3.1 & 18 & 2.2 \\
\hline$A^{*} 34$ & 4 & 0.9 & 5 & 0.6 & $B^{*} 42$ & 8 & 1.8 & 11 & 1.2 & $C^{*} 18$ & 2 & 0.4 & 4 & 0.5 \\
\hline$A^{*} 36$ & 0 & 0.0 & 4 & 0.4 & $B^{*} 44$ & 43 & 9.6 & 107 & 12.0 & & & & & \\
\hline$A^{*} 43$ & 0 & 0.0 & 0 & 0.0 & $B^{*} 45$ & 4 & 0.9 & 14 & 1.6 & & & & & \\
\hline$A^{*} 66$ & 5 & 1.1 & 9 & 1.0 & $B^{*} 46$ & 0 & 0.0 & 0 & 0.0 & & & & & \\
\hline$A^{*} 68$ & 25 & 5.6 & 58 & 6.5 & $B^{*} 47$ & 1 & 0.2 & 2 & 0.2 & & & & & \\
\hline$A^{*} 69$ & 0 & 0.0 & 4 & 0.4 & $B^{*} 48$ & 6 & 1.3 & 5 & 0.6 & & & & & \\
\hline$A^{*} 74$ & 3 & 0.7 & 16 & 1.8 & $B^{*} 49$ & 11 & 2.5 & 29 & 3.3 & & & & & \\
\hline \multirow[t]{16}{*}{$A^{*} 80$} & 4 & 0.9 & 1 & 0.1 & $B^{*} 50$ & 5 & 1.1 & 18 & 2.0 & & & & & \\
\hline & & & & & $B^{*} 51$ & 43 & 9.6 & 68 & 7.6 & & & & & \\
\hline & & & & & $B^{*} 52$ & 9 & 2.0 & 18 & 2.2 & & & & & \\
\hline & & & & & $B^{*} 53$ & 7 & 1.6 & 23 & 2.6 & & & & & \\
\hline & & & & & $B^{*} 54$ & 0 & 0.0 & 0 & 0.0 & & & & & \\
\hline & & & & & $B^{*} 55$ & 3 & 0.7 & 10 & 1.1 & & & & & \\
\hline & & & & & $B^{*} 56$ & 2 & 0.4 & 4 & 0.4 & & & & & \\
\hline & & & & & $B^{*} 57$ & 16 & 3.6 & 20 & 2.2 & & & & & \\
\hline & & & & & $B^{*} 58$ & 10 & 2.2 & 27 & 3.0 & & & & & \\
\hline & & & & & $B^{*} 59$ & 0 & 0.0 & 0 & 0.0 & & & & & \\
\hline & & & & & $B^{*} 67$ & 1 & 0.2 & 0 & 0.0 & & & & & \\
\hline & & & & & $B^{*} 73$ & 0 & 0.0 & 0 & 0.0 & & & & & \\
\hline & & & & & $B^{*} 78$ & 0 & 0.0 & 1 & 0.1 & & & & & \\
\hline & & & & & $B^{*} 81$ & 0 & 0.0 & 1 & 0.1 & & & & & \\
\hline & & & & & $B^{*} 82$ & 0 & 0.0 & 0 & 0.0 & & & & & \\
\hline & & & & & $B^{*} 83$ & 0 & 0.0 & 0 & 0.0 & & & & & \\
\hline
\end{tabular}

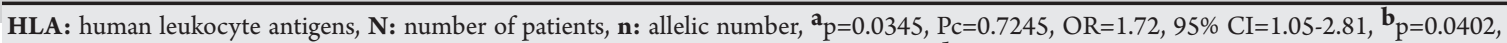

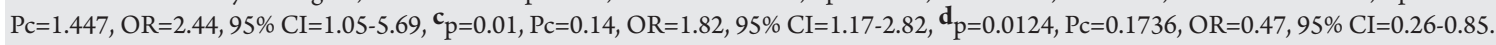


TABLE 2 - Comparison of human leukocyte antigens class-I allelic frequencies between patients with lepromatous and those with tuberculoid clinical forms of leprosy.

\begin{tabular}{|c|c|c|c|c|c|c|c|c|c|c|c|c|c|c|}
\hline \multirow[b]{2}{*}{ HLA } & \multicolumn{2}{|c|}{$\begin{array}{c}\mathrm{LL} \\
(\mathrm{N}=88)\end{array}$} & \multicolumn{2}{|c|}{$\begin{array}{c}\mathrm{TT} \\
(\mathrm{N}=46)\end{array}$} & \multirow[b]{2}{*}{ HLA } & \multicolumn{2}{|c|}{$\begin{array}{c}\mathrm{LL} \\
(\mathrm{N}=88)\end{array}$} & \multicolumn{2}{|c|}{$\begin{array}{c}\mathrm{TT} \\
(\mathrm{N}=46)\end{array}$} & \multirow[b]{2}{*}{ HLA } & \multicolumn{2}{|c|}{$\begin{array}{c}\mathrm{LL} \\
(\mathrm{N}=88)\end{array}$} & \multicolumn{2}{|c|}{$\begin{array}{c}\mathrm{T} \\
(\mathrm{N}=46)\end{array}$} \\
\hline & $\mathrm{n}$ & $\%$ & $\mathrm{n}$ & $\%$ & & $\mathrm{n}$ & $\%$ & $\mathrm{n}$ & $\%$ & & $\mathrm{n}$ & $\overline{\%}$ & $\mathrm{n}$ & $\%$ \\
\hline $\mathrm{A}^{*} 01$ & 21 & 11.9 & 8 & 8.7 & $B^{*} 07$ & 18 & 10.2 & 8 & 8.7 & $C^{*} 01$ & 5 & 2.8 & 2 & 2.2 \\
\hline $\mathrm{A}^{*} 02$ & 42 & 23.9 & 24 & 26.1 & $B^{*} 08$ & 8 & 4.5 & 1 & 1.1 & $C^{*} 02$ & 10 & 5.7 & 4 & 4.3 \\
\hline $\mathrm{A}^{*} 03$ & 13 & 7.4 & 10 & 10.9 & $B^{*} 13$ & 5 & 2.8 & 4 & 4.3 & $C^{*} 03$ & 14 & 9.7 & 4 & 3.3 \\
\hline$A^{*} 23$ & 11 & 6.3 & 4 & 4.3 & $B^{*} 15$ & 12 & 6.8 & 7 & 7.6 & $C^{*} 05$ & 8 & 5.1 & 5 & 6.5 \\
\hline $\mathrm{A}^{*} 24$ & 15 & 8.5 & 5 & 5.4 & $B^{*} 18$ & 11 & 6.3 & 6 & 6.5 & $C^{*} 06$ & 12 & 8.5 & 8 & 8.7 \\
\hline$A^{*} 25$ & 3 & 1.7 & 1 & 1.1 & $B^{*} 27$ & 1 & 0.6 & 0 & 0.0 & $C^{*} 07^{\mathcal{C}}$ & 42 & 31.8 & 16 & 18.5 \\
\hline $\mathrm{A}^{*} 26$ & 4 & 2.3 & 5 & 5.4 & $B^{*} 35^{a}$ & 18 & 10.2 & 20 & 21.7 & $C^{*} 08$ & 5 & 2.8 & 2 & 2.2 \\
\hline$A^{*} 32$ & 3 & 1.7 & 3 & 3.3 & $B^{*} 40$ & 10 & 5.7 & 3 & 3.3 & $C^{*} 16$ & 3 & 2.3 & 3 & 3.3 \\
\hline$A^{*} 33$ & 2 & 1.1 & 5 & 5.4 & $B^{*} 41$ & 2 & 1.1 & 2 & 2.2 & $C^{*} 17$ & 17 & 3.4 & 7 & 7.6 \\
\hline $\mathrm{A}^{*} 34$ & 3 & 1.7 & 0 & 0.0 & $B^{*} 42$ & 3 & 1.7 & 4 & 4.3 & $C^{*} 18$ & 1 & 0.6 & 1 & 1.1 \\
\hline$A^{*} 36$ & 0 & 0.0 & 0 & 0.0 & $B^{*} 44$ & 17 & 9.7 & 9 & 9.8 & & & & & \\
\hline $\mathrm{A}^{*} 43$ & 0 & 0.0 & 0 & 0.0 & $B^{*} 45$ & 2 & 1.1 & 1 & 1.1 & & & & & \\
\hline $\mathrm{A}^{*} 66$ & 2 & 1.1 & 1 & 1.1 & $B^{*} 46$ & 1 & 0.6 & 0 & 0.0 & & & & & \\
\hline$A^{*} 68$ & 17 & 9.7 & 3 & 3.3 & $B^{*} 47$ & 1 & 0.6 & 0 & 0.0 & & & & & \\
\hline $\mathrm{A}^{*} 69$ & 0 & 0.0 & 0 & 0.0 & $B^{*} 48$ & 1 & 0.6 & 1 & 1.1 & & & & & \\
\hline \multirow{12}{*}{$\mathrm{A}^{*} 80$} & & & & & $B^{*} 54$ & 0 & 0.0 & 0 & 0.0 & & & & & \\
\hline & & & & & $B^{*} 55$ & 1 & 0.6 & 0 & 0.0 & & & & & \\
\hline & & & & & $B^{*} 56$ & 0 & 0.0 & 0 & 0.0 & & & & & \\
\hline & & & & & $B^{*} 57$ & 9 & 5.1 & 3 & 3.3 & & & & & \\
\hline & & & & & $B^{*} 58$ & 2 & 1.1 & 3 & 3.3 & & & & & \\
\hline & & & & & $B^{*} 59$ & 0 & 0.0 & 0 & 0.0 & & & & & \\
\hline & & & & & $B^{*} 67$ & 0 & 0.0 & 0 & 0.0 & & & & & \\
\hline & & & & & $B^{*} 73$ & 0 & 0.0 & 0 & 0.0 & & & & & \\
\hline & & & & & $B^{*} 78$ & 0 & 0.0 & 0 & 0.0 & & & & & \\
\hline & & & & & $B^{*} 81$ & 0 & 0.0 & 0 & 0.0 & & & & & \\
\hline & & & & & $B^{*} 82$ & 0 & 0.0 & 0 & 0.0 & & & & & \\
\hline & & & & & $B^{*} 83$ & 0 & 0.0 & 0 & 0.0 & & & & & \\
\hline
\end{tabular}

HLA: human leukocyte antigens, N: number of patients, $\mathbf{n}$ : allelic number, LL: lepromatous leprosy, $\mathbf{T}$ : tuberculoid leprosy, ${ }^{\mathrm{a}} \mathrm{p}=0.0156, \mathrm{Pc}=0.5616$, $\mathrm{OR}=0.41,95 \% \mathrm{CI}=0.20-0.82,{ }_{\mathrm{p}}=0.0464, \mathrm{Pc}=0.6496, \mathrm{OR}=0.52,95 \% \mathrm{CI}=0.28-0.98,{ }_{\mathrm{p}}=0.0211, \mathrm{Pc}=0.2954, \mathrm{OR}=2.06,95 \% \mathrm{CI}=1.11-3.81$.

\section{DISCUSSION}

Several studies have shown association of specific HLA class-II antigens/alleles with decreased or increased risk ofleprosyin populations around the world (reviewed recently by Francheschi et al. ${ }^{17}$ ). However, consistent association of HLA class-I antigens/alleles with leprosy or its progression toward clinical forms has not been well documented.

This control-case study investigated the genetic variation present in HLA-A, -B, and -C genes and its relation with leprosy and subtypes.

Although after the correction of probabilities by multiplying $\mathrm{p}$ values by the numbers of variants tested in each locus, the results have been clearly statistically insignificant, we can note that the same association with $H L A-A^{*} 11$ and leprosy was also observed in other studies in $\mathrm{Korea}^{24}$ and South India ${ }^{20-21}$. HLA-A11 was also significantly increased in erythema nodosum leprosum (ENL) leprosy patients from North India ${ }^{25}$.

In the Turkish population, different results were observed. HLA class-I antigens A9, A10, A32, B5, B21, Bw4, Bw6, Cw1, and Cw2 were found to be significantly more frequent in patients with leprosy, while HLA class-I antigens A3, B44, B49 were significantly more frequent in controls ${ }^{19}$.

When the groups were stratified, $H L A-B^{*} 35$ and $H L A-C^{*} 04$ showed to be protective against LL leprosy, perhaps due to the best presentation of bacillus to $\mathrm{T}$ cell, while $H L A-C^{*} 07$ showed to be a 
susceptive variant. Likewise, the corrected probabilities were not more significant.

Nevertheless, some similar findings for HLA-C were observed by Shankarkumar et al. ${ }^{21}$ who found a significant increase in the frequency of $H L A-A^{*} 24: 13, B^{*} 07: 06, B^{*} 40: 16, C^{*} 07: 08$, and $C^{*} 15: 05$ and a decrease in the frequency of $H L A-A^{*} 01: 01, C^{*} 04: 11$, and $C^{*}$ 06:02 in LL patients as compared with the controls.

Nowadays, it is important to study the class-I HLA association with infectious diseases, as recent studies have shown important interactions among immune response cells and infected cells through membrane receptors. KIR3DL2 is an inhibitory receptor present principally, on the surfaces of natural killer $(\mathrm{NK}) \mathrm{cells}^{26}$, which have an important role in innate response to intracellular pathogens, such as M. leprae. Although direct evidence is lacking, KIR3DL2 seems to interact with $H L A-A 3 / 11^{27}$. The gene that codifies this protein is KIR3DL2, which, in association with $H L A-A^{*} 3 /{ }^{*} 11$, was associated to leprosy in a recent study performed by our group ${ }^{28}$. In this present study, we suppose that $H L A-A^{*} 11$ could act with KIR3DL2 for decreasing the immune response and, consequently, induce leprosy development infection.

Franceschi et al. ${ }^{28}$ also showed that KIR3DL1 associated with Bw4 and KIR2DL3 associated with $\mathrm{C} 1$ were increased in LL in comparison to TT patients. HLA-B 38 is associated with the supertype Bw $4^{29}$ (Schreuder et al., 1975), which, in this present study, was increased in leprosy patients.

$H L A-C^{*} 07, H L A-C^{*} 12$, and $H L A-C^{*} 16$ are considered part of group $C 1$, which is a specific ligant for KIR2DL2/2DL3/2DS2 ${ }^{30}$, while $H L A-C^{*} 04$ is part of group C2, which is ligant for KIR2DL1/2DS1. The underlying mechanism regarding the association between these genes and leprosy could be correlated to major or minor inhibitor effect of these associations.

In summary, although our results do not support previous findings that HLA class-I alleles play a role in leprosy pathogenesis, we suggest new studies because of the importance of the association between the HLA and KIR in the innate immune response to leprosy.

\section{ACKNOWLEDGMENTS}

The authors are thankful to the donors and patients who took part on this study; to Maria Lúcia Ribas, Maria Aparecida da Silva, and Paulo Roberto Peixoto for their collaboration in collecting patients' data; and to Fabiano Cavalcante de Melo and Marco Antonio Braga for their technical assistance in genotyping.

\section{CONFLICT OF INTEREST}

The authors declare that there is no conflict of interest.

\section{FINANCIAL SUPPORT}

This study received financial support from the Conselho Nacional de Desenvolvimento Científico e Tecnológico $(\mathrm{CNPq})$ from the Ministry of Science and Technology, Fundação Araucária from Paraná Government and Ministry of Healthy (Brazil).

\section{REFERENCES}

1. Hansen A. Bacillus leprae. Norsk Mag Laegevidenskaben 1874; 9:1-21.

2. World Health Organization. Global leprosy situation. Weekly Epidemiol Record 2010; 85:337-348

3. Ridley DS, Jopling WH. Classification of leprosy according to immunity: a five group system. Int J Leprosy 1966; 34:255-273.
4. Germain RN, Margulies DH. The biochemistry and cell biology of antigen processing and presentation. An Rev Immunol 1993; 11:403-450.

5. Rani R, Fernandez-Vina MA, Zaheer SA, Beena KR, Stastny P. Study of HLA class II alleles by PCR oligotyping in leprosy patients from north India. Tissue Antigens 1993; 42:133-137.

6. Zerva L, Cizman B, Mehra NK, Alahari SK, Murali R, Zmijewski CM, et al. Arginine at positions 13 or 70-71 in pocket 4 of HLA-DRB1 alleles is associated with susceptibility to Tuberculoid Leprosy. J Exp Med 1996; 183:829-836.

7. Visentainer JE, Tsuneto LT, Serra MF, Peixoto PR, Petzl-Erler ML. Association of leprosy with HLA-DR2 in a Southern Brazilian population. Braz J Med Biol Res 1997; 30:51-59.

8. Tosh K, Ravikumar M, Bell JT, Meisner S, Hill AV, Pitchappan R. Variation in MICA and MICB genes and enhanced susceptibility to paucibacillary leprosy in South India. Hum Mol Genet 2006; 15:2880-2887.

9. Joko S, Numaga J, Kawashima H, Namisato M, Maeda H. Human leukocyte antigens in forms of leprosy among Japanese patients. Int J Lepr Other Mycobact Dis 2000; 68:49-56.

10. Vanderborght PR, Pacheco AG, Moraes ME, Antoni G, Romero M, Verville A, et al. HLA-DRB $1^{*} 04$ and $\mathrm{DRB} 1^{*} 10$ are associated with resistance and susceptibility, respectively, in Brazilian and Vietnamese leprosy patients. Genes Immun 2007; 8:320-324.

11. Zhang F, Liu H, Chen S, Wang C, Zhu C, Zhang L, et al. Evidence for an association of HLA-DRB1* 15 and $\mathrm{DRB} 1^{*} 09$ with leprosy and the impact of DRB $1^{*} 09$ on disease onset in a Chinese Han population. BMC Medical Genetics 2009; 10:133-138.

12. da Silva SA, Mazini PS, Reis PG, Sell AM, Tsuneto LT, Peixoto PR, et al. HLA-DR and HLA-DQ alleles in patients from the south of Brazil: markers for leprosy susceptibility and resistance. BMC Infect Dis 2009; 9:134-140.

13. Hsieh NK, Chu CC, Lee NS, Lee HL, Lin M. Association of HLA-DRB1*0405 with resistance to multibacillary leprosy in Taiwanese. Hum Immunol 2010; 71:712-716.

14. Meyer CG, MayJ, Stark K. Human leukocyte antigens in tuberculosis and leprosy. Trends Microbiol 1998; 6:148-154

15. Fitness J, Tosh K, Hill AV. Genetics of susceptibility to leprosy. Genes Immun 2002; 3:441-453.

16. Mira MT. Genetic host resistance and susceptibility to leprosy. Microbes Infect 2006; 8:1124-1131.

17. Francheschi DS, Sacramento WS, Mazini OS, Visentainer JE. Hanseníase no Mundo Moderno: O Que Sabemos Sobre a Influência Genética do Hospedeiro no seu Controle? Arq Med 2009; 23:159-165.

18. Wang LM, Kimura A, Satoh M, Mineshita S. HLA linked with leprosy in southern China: HLA-linked resistance alleles to leprosy. Int J Lepr Other Mycobact Dis 1999; 67:403-408.

19. Koçak M, Balci M, Pençe B, Kundakçi N. Associations between human leukocyte antigens and leprosy in the Turkish population. Clin Exp Dermatol 2002; 27:235-239.

20. Shankarkumar U. HLA associations in leprosy patients from Mumbai, India. Lepr Rev 2004; 75:79-85.

21. Shankarkumar U, Ghosh K, Badakere S, Mohanty D. Novel HLA Class I Alleles Associated with Indian Leprosy Patients. J Biomed Biotechnol 2003; 3:208-211.

22. Probst CM, Bompeixe EP, Pereira NF, Dalalio MMO, VisentainerJE, Tsuneto LT, et al. HLA polymorphism and evaluation of European, African, and Amerindian contribution to the white and mulatto populations from Paraná, Brazil. Hum Biol 2000; 72:597-617.

23. Parra FC, Amado RC, Lambertucci JR, Rocha J, Antunes CM, Pena SD. Color and genomic ancestry in Brazilians. Proc Natl Acad Sci USA 2003; 100:177-182.

24. Kim SJ, Choi IH, Dahlberg S, Nisperos B, Kim JD, Hansen JA. HLA and leprosy in Koreans. Tissue Antigens 1987; 29:146-153.

25. Agrewala JN, Ghei SK, Sudhakar KS, Girdhar BK, Sengupta U. HLA antigens and erythema nodosum leprosum (ENL). Tissue Antigens 1989; 33:486-487.

26. Rajagopalan S, Long EO. Understanding how combinations of HLA and KIR genes influence disease. J Exp Med 2005; 201:1025-1029.

27. Hansasuta P, Dong T, Thananchai H, Weekes M, Willberg C, Aldemir H, et al. Recognition of HLA-A3 and HLA-A11 by KIR3DL2 is peptide-specific. Eur J Immunol 2004; 34:1673-1679.

28. Franceschi DS, Mazini PS, Rudnick CC, Sell AM, Tsuneto LT, Melo FC, et al. Association between killer-cell immunoglobulin-like receptor (KIR) genotypes and leprosy in Brazil. Tissue Antigens 2008; 72:478-482.

29. Schreuder I, D'Amaro JD, Sandberg L, van Rood JJ. Participation of the antigen W16 into two subtypic determinants. Tissue Antigens 1975; 5:142-144.

30. Boyton RJ, Altmann DM. Natural killer cells, killer immunoglobulin-like receptors and human leukocyte antigen class I in disease. Clin Exp Immunol 2007; 149:1-8. 